\title{
GROWTH AND YIELD RESPONSE OF WATERMELON TO IN-ROW PLANT SPACINGS AND MYCORRHIZA
}

\author{
Dean Ban' ${ }^{1}$, Smiljana Goreta Ban²*, Milan Oplanićc ${ }^{1}$ Josipa Horvat ${ }^{1}$, Bruno Novak ${ }^{3}$, Katja Žanić², \\ and Dragan Žnidarčič ${ }^{4}$
}

\begin{abstract}
Worldwide, a significant increase in watermelon (Citrullus lanatus [Thunb.] Matsum. \& Nakai) growing areas has been registered in the last few years. In-row plant spacing has a significant effect on the growth and yield of watermelon, and can enhance competition for water and nutrients. The aim of this study was to investigate the effects of in-row plant spacing $(1.0,1.5,2.0$ and $2.5 \mathrm{~m})$ and arbuscular mycorrhiza (AM) fungi Glomus mosseae inoculations on watermelon growth and yield under field conditions during 2003, 2004, and 2005 year. In 2003, the main vine length, number of leaves, and number of lateral branches were increased quadratically as the in-row plant spacing increased from 1.0 to 2.5 . With an increase in the in-row plant spacing the early yield of watermelon decreased in 2004, while the fruit number decreased in 2003 and 2004. The total yield and fruit number decreased with an increase in the in-row plant spacing in all 3 yr; however, the fruit mass increased at wider plant spacings in 2003. Mycorrhizal inoculation increased the main vine length and the number of lateral branches in 2003. Compared to non-mycorrhizal plants, mycorrhizal plants presented higher early yield in 2005 and a higher early fruit number in 2003 and 2005. Mycorrhizal inoculation increased total yield in 2005; however, the fruit weight was not affected by mycorrhizal inoculation during early or total harvest. In this study, an in-row plant spacing of $1.0 \mathrm{~m}$ provided the best early and total yield while maintaining high fruit weight. The growth and yield enhancement of watermelon due to mycorrhizal colonization was not consistent; therefore, mycorrhizal inoculation could not be recommended as a standard production practice.
\end{abstract}

Key words: Arbuscular mycorrhiza, Citrullus lanatus, Glomus mosseae, fruit, plant density, vegetative growth.

$\mathrm{T}$ he production and consumption of watermelon (Citrullus lanatus [Thunb.] Matsum. \& Nakai) are greater than that of any other species in the Cucurbitaceae family (Robinson and Decker-Walters, 1997). In Croatia, an increase in the consumption and production of watermelon has been observed in the last $15 \mathrm{yr}$ (FAOSTAT, 2010). Although, the acreage of watermelon in Croatia increased, the average yields are still rather low on some farms $\left(18 \mathrm{tha}^{-1}\right)$.

Cultural techniques for obtaining profitable watermelon yields include the usage of polyethylene (PE) mulches and drip irrigation (Ban et al., 2009). Other measures such as the implementation of plant density strategies, nutrient management and arbuscular mycorrhiza (AM) inoculation have been reported to have a positive impact

${ }^{1}$ Institute of Agriculture and Tourism, Carla Huguesa 8, 52440 Poreč, Croatia.

${ }^{2}$ Institute for Adriatic Crops, Put Duilova 11, 21000 Split, Croatia. *Corresponding author (smilja@krs.hr).

${ }^{3}$ University of Zagreb, Faculty of Agriculture, Svetošimunska 25, 10000 Zagreb, Croatia.

${ }^{4}$ University of Ljubljana, Biotechnical Faculty, Jamnikarjeva 101, 1000 Ljubljana, Slovenia.

Received: 14 January 2011.

Accepted: 28 August 2011. on watermelon yield (Duthie et al., 1999; Kaya et al., 2003; Goreta et al., 2005).

Higher yield per area in watermelon is related to dense in-row plant spacings (NeSmith, 1993; Huitron-Ramirez et al., 2009). High plant density is recommended in watermelon seed production because more fruit per area is achieved at a denser spacing (Edelstein and Nerson, 2002). When the number of plants per area is increased, the fruit number per area is enhanced, but the yield and fruit number per plant is reduced (Brinen et al., 1979; NeSmith, 1993; Duthie et al., 1999; Sanders et al., 1999; Motsenbocker and Arancibia, 2002). Thus, the relatively high yield at denser in-row spacings is due to a high fruit number per area (NeSmith, 1993; Duthie et al., 1999). However, the fruit weight could be negatively impacted by high plant densities (Brinen et al., 1979; Sanders et al., 1999; Motsenbocker and Arancibia, 2002; Goreta et al., 2005). Research on diverse vegetable crops have shown that yield increases linearly when the in-row plant spacing is reduced (Knavel, 1988; Žnidarčič and Osvald, 1999; Ban et al., 2006).

Dense spacing designs may increase competition for water and fertilizers, which results in inadequate vegetative growth and low yields (Knavel, 1988). Arbuscular mycorrhiza inoculation improves water usage 
under irrigated and non-irrigated systems and enhances soil mineral uptake, especially P (Sari et al., 2002; Kaya et al., 2003; Meding and Zasoski, 2008). In previous studies, AM fungi Glomus mosseae had a positive effect on different plant species (Chandanie et al., 2006; Smith and Read, 2008). Similarly, watermelon plants inoculated with $G$. clarum achieved improved vegetative growth and higher yields (Kaya et al., 2003).

The goal of the present study was to determine the effects of in-row plant spacing and AM fungi inoculation on watermelon growth and yield under Mediterranean growing conditions.

\section{MATERIALS AND METHODS}

The experiments were conducted on a farm in Pula (445' $\left.{ }^{\circ} \mathrm{N}, 13^{\circ} 51^{\prime} \mathrm{E}, 10 \mathrm{~m} . \mathrm{a} . \mathrm{s} .1.\right)$, which is located in the Mediterranean area of Croatia, in 2003, 2004, and 2005. A two-factorial experiment was designed as a split-plot scheme, with three replicates. Watermelon cv. Fantasy $F_{1}$ (Known-You Seed, Co., Kaohsung, Taiwan) was planted at in-row spacings of 1.0, 1.5, 2.0 and $2.5 \mathrm{~m}$ (main plot) with or without inoculation with AM fungi $G$. mosseae (sub-plot). The main plot contained three rows mulched with back polyethylene film, with a between-row spacing equal to $2 \mathrm{~m}$. The main plot area was $192 \mathrm{~m}^{2}(6 \mathrm{~m} \times 32$ $\mathrm{m})$, and the sub-plot was a half of main plot $96 \mathrm{~m}^{2}(6 \mathrm{~m} \times$ $16 \mathrm{~m})$. Main plots were separated from other treatments by edge row from right and left side.

In all $3 \mathrm{yr}$, transplants were grown in a heated greenhouse. In 2003, transplants were grown in polystyrene trays with a cell volume of $100 \mathrm{~mL}$ (40 cells per tray). Alternatively, in 2004 and 2005, transplants were grown in polystyrene trays with a cell volume of $60 \mathrm{~mL}$ (84 cells per tray). Polystyrene trays were handfilled with the Klasmann peat-based growing substrate (pH 6-6.5; $180 \mathrm{mg} \mathrm{N} \mathrm{L}^{-1} ; 210 \mathrm{mg} \mathrm{P}_{2} \mathrm{O}_{5} \mathrm{~L}^{-1} ; 250 \mathrm{mg}$ $\mathrm{K}_{2} \mathrm{O} \mathrm{L}^{-1} ; 85 \mathrm{mg} \mathrm{MgO} \mathrm{L}{ }^{-1}+$ microelements; KlasmannDeilmann $\mathrm{GmbH}$, Geeste, Germany), and one seed per cell was sown on 26 March 2003, 4 April 2004, and 6 April 2005. Seedlings were irrigated every day and were fertilized once a week with a commercial nutrient solution Folifertil-T (Petrokemija d.o.o., Kutina, Croatia; 12\% N, $4 \% \mathrm{P}_{2} \mathrm{O}_{5}$ and $6 \% \mathrm{~K}_{2} \mathrm{O}+$ microelements).

The winter forage crops [cabbage (Brassica oleracea L. var. capitata), spinach (Spinacia oleracea L.), and kale (Brassica oleracea L. var. sabauda)] were harvested 1-mo before watermelon planting, and the experimental fields were plowed to a depth of $30 \mathrm{~cm}$. Prior to plowing, organic manure was incorporated at a rate of $40 \mathrm{t} \mathrm{ha}^{-1}$. After the experimental fields were plowed, $1000 \mathrm{~kg} \mathrm{ha}^{-1}$ of mineral fertilizer $5 \mathrm{~N}-8.7 \mathrm{P}-24.9 \mathrm{~K}$ was incorporated into the soil with a rotary cultivator. Subsequently, herbicide (napropamide; N,N-diethyl-2-[1-naphthalenyloxy]propanamide) was applied to the soil with a rotary cultivator at a rate of $4 \mathrm{~L} \mathrm{ha}^{-1}$.
Drip tape was placed beneath the black PE film, and with emitter spacing at $20 \mathrm{~cm}$ (capacity of $4 \mathrm{~L} \mathrm{~h}^{-1}$ ). Transplants with 3 to 4 true leaves were planted on 8 May 2003, 23 May 2004, and 22 May 2005.

Inocula of AM fungi $G$. mosseae were obtained using corn (Zea mays L.) as a host plant. Corn seed was grown in pots $(300 \mathrm{~mL})$ filled with a substrate composed of sand:expanded clay:inoculum at a 50:45:5 ratio for 3-mo. To obtain the inoculum, the stems were cut and discarded, and the roots were ground into $0.5 \mathrm{~cm}$ pieces. Approximately $5 \mathrm{~g}$ of the inoculum was added to each planting hole immediately before planting, according to the method of Kaya et al. (2003).

Soil insecticide (chlorpyrifos; $O, O$-diethyl $O$-[3,5,6trichloro-2-pyridyl]phosphorothioate) was added to each hole at a rate of $3 \mathrm{~kg} \mathrm{ha}^{-1}$. After planting, a few granules of limacid Mesurol G (methiocarb) were spread near each plant at a rate of $4 \mathrm{~kg} \mathrm{ha}^{-1}$.

Fertigation was conducted five times during the vegetative phase by applying water-soluble fertilizer (Kristalon, Hydro Agri, Rotterdam, The Netherlands). In total, fertilizer was added at a rate of $71 \mathrm{~kg} \mathrm{~N} \mathrm{ha}^{-1}, 97 \mathrm{~kg} \mathrm{P}_{2} \mathrm{O}_{5}$ ha $^{-1}$ and $96 \mathrm{~kg}$ $\mathrm{K}_{2} \mathrm{O}$ ha $^{-1}$. Fertigation was conducted $7 \mathrm{~d}$ after planting and was reapplied every $10 \mathrm{~d}$. Each year, during vegetative growth phase, plants were treated twice every year against Pseudoperonospora cubensis and Aphides with metalaxyl (methyl N-[2,6-dimethylphenyl]-N-[(methoxyacetyl)]-DL-alaninate) and alpha-cypermethrin (R-cyano[3-phenoxyphenyl]methyl[1S,3S]-rel-3-[2,2-dichloroethenyl]-2,2-dime thylcyclopropanecarboxylate), respectively. Every year, the rows between the beds were treated once with the nonselective contact herbicide (glufosinate-ammonium; 2-amino-4[hydroxymethylphosphinyl]butanoic acid monoammonium salt). Before the vines reached a length of $40 \mathrm{~cm}$, the herbicide was applied at a rate of $6 \mathrm{~L} \mathrm{ha}^{-1}$. Subsequently, weeds were manually removed when necessary.

In 2003, 2004, and 2005, vegetative growth parameters (main vine length, number of leaves on the main vine, number of lateral branches, and main vine diameter) were measured $22 \mathrm{~d}$ after planting (DAP), 29 DAP, and 19 DAP, in 2003, 2004, and 2005, respectively. In total, 15 plants per treatment were evaluated.

Watermelons were harvested by hand when the fruit matured. The watermelons were picked by experienced persons and in general fruit were considered mature when the tendril nearest to fruit start to dry, and color of fruit on the bottom side changed from creamy white to yellowish. In all $3 \mathrm{yr}$, three harvests were conducted during maturation (from 8-21 July 2003, 11-22 August 2004, and 25 July-6 August 2005). Fruits were measured and weighed during harvest and the early (first harvest) and total yield were determined. Damaged fruit and fruit smaller than $3 \mathrm{~kg}$ were considered non-marketable fruit.

To determine the significance of in-row plant spacing, mycorrhiza inoculation and interaction effects, data 
were analyzed separately for each year by conducting an ANOVA using proc GLM from SAS software (SAS Institute, 1999). To identify trends in the in-row plant spacing, linear and quadratic contrasts were employed.

\section{RESULTS AND DISCUSSION}

\section{Vegetative growth}

In-row plant spacing and mycorrhizal inoculation weakly influenced watermelon vegetative growth, and interactions among variables were not observed (Table 1). In-row plant spacing had an effect on the main vine length, number of leaves, and number of lateral branches in 2003, and a quadratic response was observed as the in-row plant spacing increased from 1.0 to 2.5 (Table 1). Maynard and Scott (1998) distinguished types of melon growth based on the vine length, which probably could be the case with watermelon cultivars. In general, early watermelon cultivars have a shorter vegetative period and less vegetative growth than late cultivars. In the present study, an early watermelon cultivar was planted. Thus, maximum vegetative potential may be achieved with denser plant spacings than with late watermelon cultivars, especially in the early stages of growth when the measurements were performed. Except in 2003, when the main vine length and the number of lateral branches increased, mycorrhizal inoculation did not have a significant effect on watermelon vegetative growth (Table 1). In a previous study, the effect of G. mosseae fungi on watermelon transplant growth was inconsistent, probably due to the absence of drought stress or stress caused by low mineral availability (Ban et al., 2007). Mycorrhizal colonization provides superior results in stressed environments (Smith and Read, 2008).

The difference in plant early vegetative growth between years was mostly due to different planting dates. In 2003, the planting was at the beginning of May (8 May), while in 2004 and 2005 planting was at 23 May and 22 May, respectively. The weather conditions (soil and air temperatures) are more favorable to watermelon growth in later planting dates, and therefore we have observed more vigorous plants in 2004 and 2005. Also, if we compare 2004 and 2005, the more vigorous plants were observed in 2004 because the observations were done 29 days after planting (DAP) as compared to 19 DAP in 2005.

\section{Yield and yield components}

The early yield of watermelon decreased with an increase in the in-row plant spacing in 2004, and the fruit number decreased in 2003 and 2004 (Table 2). Fruit mass in early harvest increased with an increase in the in-row plant spacing in 2003; however, plant spacing did not have an effect in 2004 and 2005 (Table 2). In-row plant spacing had a stronger effect on the total yield than on the early yield (Table 2 and 3). In all $3 \mathrm{yr}$, the total yield and fruit number per hectare decreased with an increase in the inrow plant spacing, and the fruit mass increased in 2003 (Table 3).

Our results confirmed the findings of other studies, which suggest that fruit yield increases with an increase in plant density due to an increase in the plant number per area and the number of fruit per area (Brinen et al., 1979; NeSmith, 1993; Duthie et al., 1999; Sanders et al., 1999; Motsenbocker and Arancibia, 2002; Goreta et al., 2005). Frequently, the average fruit weight decreases with an increase in the plant density (Brinen et al., 1979; Sanders et al., 1999; Motsenbocker and Arancibia, 2002; Goreta et al., 2005); however, in our study, this relationship was only observed in 2003. In studies with narrower in-row plant spacings, the effect of plant spacing on the fruit weight was more pronounced than in the present study. Moreover, a stronger reduction in fruit weight was observed when the in-row plant spacing was less than 1.0 m (NeSmith, 1993; Sanders et al., 1999; Motsenbocker and Arancibia, 2002).

The early yield of mycorrhizal plants $\left(16.0 \mathrm{t} \mathrm{ha}^{-1}\right)$ was greater than that of non-mycorrhizal plants $\left(13.8 \mathrm{t} \mathrm{ha}^{-1}\right)$ in 2005. In addition, in 2003 and 2005, the early fruit number of mycorrhizal plants was greater than that of nonmycorrhizal plants (Table 2). Mycorrhizal inoculation

Table 1. Effects of in-row plant spacing and mycorrhiza on watermelon main vine length, diameter and number of leaves, and number of lateral branches 2003, 2004, and 2005 .

\begin{tabular}{|c|c|c|c|c|c|c|c|c|c|c|c|c|}
\hline \multirow[b]{2}{*}{ Treatment } & \multicolumn{3}{|c|}{ Main vine length } & \multicolumn{3}{|c|}{$\begin{array}{c}\mathrm{N}^{\circ} \text { of leaves on main } \\
\text { vine }\end{array}$} & \multicolumn{3}{|c|}{$\mathrm{N}^{\circ}$ of lateral branches } & \multicolumn{3}{|c|}{ Main vine diameter } \\
\hline & 2003 & 2004 & 2005 & 2003 & 2004 & 2005 & 2003 & 2004 & 2005 & 2003 & 2004 & 2005 \\
\hline & $\longrightarrow$ & $-\mathrm{cm}-$ & - & & & & & & & & $-\mathrm{mm}$ & 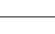 \\
\hline \multicolumn{13}{|l|}{ In-row spacing (S) } \\
\hline $1.0 \mathrm{~m}$ & 18.4 & 51.7 & 31.8 & 5.1 & 12.3 & 10.7 & 1.7 & 4.1 & 2.6 & 4.7 & 4.8 & 3.6 \\
\hline $1.5 \mathrm{~m}$ & 19.4 & 54.7 & 29.0 & 5.7 & 13.0 & 10.3 & 2.0 & 4.2 & 2.9 & 4.9 & 4.9 & 3.7 \\
\hline $2.0 \mathrm{~m}$ & 23.0 & 51.7 & 28.5 & 6.4 & 12.0 & 10.3 & 2.3 & 3.7 & 3.0 & 4.9 & 4.8 & 3.7 \\
\hline $2.5 \mathrm{~m}$ & 22.6 & 55.6 & 33.2 & 6.0 & 12.6 & 11.0 & 2.5 & 4.0 & 3.1 & 5.1 & 4.6 & 3.9 \\
\hline \multicolumn{13}{|l|}{ Mycorrhiza (M) } \\
\hline Non-mycorrhizal & 18.5 & 52.1 & 31.1 & 5.6 & 12.4 & 10.5 & 2.0 & 4.0 & 2.9 & 4.8 & 4.8 & 3.7 \\
\hline Mycorrhizal & 23.2 & 54.7 & 30.1 & 6.0 & 12.5 & 10.6 & 2.3 & 4.0 & 2.9 & 5.0 & 4.8 & 3.8 \\
\hline \multicolumn{13}{|l|}{ Significance $^{1}$} \\
\hline $\mathrm{S}$ & $\mathrm{Q}^{*}$ & ns & ns & $\mathrm{L}^{*} \mathrm{Q} * *$ & ns & ns & $\mathrm{Q}^{*}$ & ns & ns & ns & ns & ns \\
\hline M & $* *$ & ns & ns & ns & ns & ns & $*$ & ns & $\mathrm{ns}$ & $\mathrm{ns}$ & $\mathrm{ns}$ & ns \\
\hline $\mathrm{S} \times \mathrm{M}$ & ns & ns & ns & ns & ns & ns & ns & ns & ns & ns & ns & ns \\
\hline
\end{tabular}

${ }^{1}$ Significant effects are denoted as: ns, ${ }^{*},{ }^{*}$, , non significant or significant at $\mathrm{P} \leq 0.05,0.01$, respectively. In-row effects were linear (L) or quadratic (Q). 
Table 2. Effects of in-row plant spacing and mycorrhiza on early (first) harvest marketable yield, fruit number, and fruit weight of watermelon in 2003, 2004 , and 2005.

\begin{tabular}{|c|c|c|c|c|c|c|c|c|c|}
\hline \multirow[b]{2}{*}{ Treatment } & \multicolumn{3}{|c|}{ Early yield } & \multicolumn{3}{|c|}{$\mathrm{N}^{\circ}$ of fruit per ha } & \multicolumn{3}{|c|}{ Fruit weight } \\
\hline & 2003 & 2004 & 2005 & 2003 & 2004 & 2005 & 2003 & 2004 & 2005 \\
\hline & 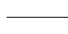 & $\mathrm{t} \mathrm{ha}^{-1}$ & - & & & & $\longrightarrow$ & $\mathrm{kg}$ fruit & 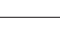 \\
\hline \multicolumn{10}{|l|}{ In-row spacing $(\mathrm{S})$} \\
\hline $1.0 \mathrm{~m}$ & 16.2 & 20.8 & 15.9 & 1867 & 2700 & 2203 & 7.8 & 7.7 & 7.2 \\
\hline $1.5 \mathrm{~m}$ & 16.2 & 14.5 & 14.1 & 1431 & 1801 & 2012 & 7.9 & 8.1 & 7.0 \\
\hline $2.0 \mathrm{~m}$ & 16.4 & 13.6 & 16.6 & 1350 & 1788 & 2289 & 8.3 & 7.6 & 7.3 \\
\hline $2.5 \mathrm{~m}$ & 15.0 & 13.7 & 12.7 & 783 & 1803 & 1985 & 8.4 & 7.9 & 6.5 \\
\hline \multicolumn{10}{|l|}{ Mycorrhiza (M) } \\
\hline Non-mycorrhizal & 16.4 & 15.8 & 13.8 & 1194 & 2033 & 1982 & 8.2 & 7.8 & 7.0 \\
\hline Mycorrhizal & 15.5 & 15.6 & 16.0 & 1521 & 2014 & 2263 & 8.0 & 7.9 & 7.1 \\
\hline \multicolumn{10}{|l|}{ Significance $^{1}$} \\
\hline $\mathrm{S}$ & ns & $\mathrm{L}^{* *} \mathrm{Q} * *$ & ns & $\mathrm{L}^{* *}$ & $\mathrm{~L}^{* *} \mathrm{Q} * *$ & ns & $\mathrm{L}^{* *}$ & ns & ns \\
\hline M & ns & $\mathrm{ns}$ & $*$ & $*$ & ns & $*$ & ns & ns & ns \\
\hline $\mathrm{S} \times \mathrm{M}$ & ns & ns & ns & ns & $*$ & ns & ns & ns & ns \\
\hline
\end{tabular}

${ }^{1}$ Significant effects are denoted as: $\mathrm{ns}, *$, **, non significant or significant at $\mathrm{P} \leq 0.05,0.01$, respectively. In-row effects were linear (L) or quadratic (Q).

Table 3. Effects of in-row plant spacing and mycorrhiza on total yield, number of fruit, and fruit weight of watermelon in 2003 , 2004 , and 2005.

\begin{tabular}{|c|c|c|c|c|c|c|c|c|c|}
\hline \multirow[b]{2}{*}{ Treatment } & \multicolumn{3}{|c|}{ Total yield } & \multicolumn{3}{|c|}{$\mathrm{N}^{\circ}$ of fruit per ha } & \multicolumn{3}{|c|}{ Fruit weight } \\
\hline & 2003 & 2004 & 2005 & 2003 & 2004 & 2005 & 2003 & 2004 & 2005 \\
\hline & 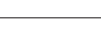 & $-\mathrm{t} \mathrm{ha}^{-1}$ & - & & & & $\longrightarrow$ & $\mathrm{kg}$ frui & . \\
\hline \multicolumn{10}{|l|}{ In-row spacing (S) } \\
\hline $1.0 \mathrm{~m}$ & 91.5 & 66.9 & 42.4 & 8700 & 9530 & 6298 & 10.5 & 7.1 & 6.8 \\
\hline $1.5 \mathrm{~m}$ & 62.2 & 48.6 & 38.2 & 5319 & 6569 & 5793 & 11.9 & 7.4 & 6.8 \\
\hline $2.0 \mathrm{~m}$ & 52.3 & 41.4 & 37.7 & 4300 & 5590 & 5720 & 12.4 & 7.4 & 6.6 \\
\hline $2.5 \mathrm{~m}$ & 43.8 & 38.6 & 29.1 & 3150 & 5202 & 4583 & 13.5 & 7.5 & 6.3 \\
\hline \multicolumn{10}{|l|}{ Mycorrhiza (M) } \\
\hline Non-mycorrhizal & 62.2 & 48.1 & 34.4 & 5320 & 6762 & 5340 & 12.2 & 7.2 & 6.5 \\
\hline Mycorrhizal & 62.8 & 49.6 & 39.4 & 5415 & 6684 & 5857 & 11.9 & 7.5 & 6.8 \\
\hline \multicolumn{10}{|l|}{ Significance $^{1}$} \\
\hline S & $\mathrm{L} * * \mathrm{Q}^{* *}$ & $\mathrm{~L}^{* *} \mathrm{Q} * *$ & $\mathrm{~L}^{* *}$ & $\mathrm{~L}^{* *} \mathrm{Q} * *$ & $\mathrm{~L}^{* *} \mathrm{Q} * *$ & $\mathrm{~L} * *$ & $\mathrm{~L}^{* *}$ & ns & ns \\
\hline M & ns & ns & $* *$ & ns & ns & $\mathrm{ns}$ & $\mathrm{ns}$ & ns & ns \\
\hline $\mathrm{S} \times \mathrm{M}$ & ns & $*$ & $*$ & ns & ns & ns & ns & ns & ns \\
\hline
\end{tabular}

${ }^{1}$ Significant effects are denoted as: ns, ${ }^{*},{ }^{* *}$, non significant or significant at $\mathrm{P} \leq 0.05,0.01$, respectively. In-row effects were linear (L) or quadratic (Q).

increased the total yield in 2005, and an interaction between in-row plant spacing and mycorrhizal inoculation was observed in 2004 and 2005. Alternatively, the fruit weight was not affected by mycorrhizal inoculation during early or total harvest (Tables 2 and 3). At the time of flowering and fruit set, weather conditions (low air and soil temperatures) could be the factor that limits watermelon yield. Our results suggest that mycorrhiza inoculation contributed to overcoming these conditions and inoculated plants were able to achieve better early fruit set. Later in the season, when weather conditions and cultivation measures are not limiting the effect of mycorrhiza is less pronounced which was confirmed with lack of response of total fruit number and fruit mass on inoculation.

The watermelon yield decreased substantially from 2003 to 2005 because the same field was cultivated. Therefore, mycorrhizal inoculation had a positive effect on the early and total yield in the third year (2005) because the plants were exposed to stress caused by watermelon growth under monoculture. Similar results were observed in a study performed by Sari et al. (2002), which demonstrated that $G$. mosseae increased the garlic yield in the second year.

Although Glomus spp. are the most common, AM fungi species can colonize about $80 \%$ of all terrestrial plant roots (Akiyama and Hayashi, 2002), some degree of plant selectivity in the receptiveness of other Glomus spp. and other AM fungi is often observed (Smith and Read, 2008). Glomus mosseae is often used in cucumber production in the presence of soil born diseases as well as under drought stress or low $\mathrm{P}$ availability (Chandanie et al., 2006; Zhang et al., 2008). However, significant positive effects on the watermelon biomass and yield have been observed following inoculation with $G$. clarum in the presence and absence of drought stress conditions (Kaya et al., 2003). Thus, appropriate plant species-AM fungi combinations must be determined to enhance the benefits of symbiosis (Sensory et al., 2007). In a study on commercial inocula of mixed mycorrhizal fungi species, early growth, and transplant establishment were enhanced under stressful conditions; however, the effect of inoculation on yield was inconsistent. As a result, mycorrhizal inoculation could not be introduced as a standard growing technology (Westphal et al., 2008). To the best of our knowledge, the effect of G. mosseae on watermelon yield or growth has not been established. Mycorrhizal colonization of watermelon roots with $G$. mosseae was confirmed in the present study by inspection under a light microscope (data not shown), yet the effect of inoculation on the observed parameters was variable. Although mycorrhizal inoculation enhanced the early 
and total yield in the third year of the present study, a continuous effect that would support a recommendation as a standard production practice was not observed.

\section{CONCLUSIONS}

In conclusion, based on the results of the present study, an in-row plant spacing of $1.0 \mathrm{~m}$ enhances the early and total yield while maintaining high fruit weight. Yield enhancement by mycorrhizal colonization was inconsistent; thus, we cannot support the standard application of $G$. mosseae in commercial watermelon production. The effect of AM colonization remains an open question, and further testing of other AM species may provide more consistent results.

\section{Respuesta del crecimiento vegetativo y producción} de sandía a diferentes distancias entre plantas y a micorrizas. En los últimos años se ha registrado un significativo aumento en las áreas cultivadas con sandía (Citrullus lanatus [Thunb.] Matsum. \& Nakai) a nivel mundial. La distancia entre plantas en la hilera tiene un efecto significativo en su crecimiento y rendimiento, y puede generar competencia por agua y nutrientes. Se estudiaron los efectos de diferentes distancias en hilera $(1,0 ; 1,5 ; 2,0$ y $2,5 \mathrm{~m})$ y de inoculaciones con micorrizas arbusculares (AM), Glomus mosseae, sobre el crecimiento y el rendimiento de la sandía. El ensayo se llevó a cabo en condiciones de campo durante 2003, 2004, y 2005. En el año 2003 se observó un aumento cuadrático sobre la longitud del tallo principal, número de hojas y ramas laterales debido al aumento de la distancia entre plantas de 1,0 a 2,5 m. En 2004, con un aumento de separación entre plantas se redujo el rendimiento temprano, y el número de frutos disminuyó en 2003 y 2004. Durante el ensayo, la producción total y el número de frutos disminuyeron con el aumento de la separación entre plantas, mientras en el año 2003 aumentó el peso de los frutos. La inoculación de micorrizas aumentó la longitud del tallo principal y el número de ramas laterales el 2003. Las plantas micorrizadas presentaron un mayor rendimiento temprano (2005) y número de frutos (2003 y 2005). La inoculación aumentó la producción total el 2005, mientras el peso del fruto no fue afectado durante la cosecha temprana o final. En este estudio, el marco de plantación de 1,0 m mostró la producción temprana y total más alta manteniendo un alto peso del fruto. El crecimiento y aumento del rendimiento de la sandía, debido a la micorrización no fueron consistentes, por lo tanto, la inoculación de micorrizas no puede ser recomendada como una práctica de producción estándar.

Palabras clave: Citrullus lanatus, crecimiento vegetativo, fruta, Glomus mosseae, densidad de plantas, micorrizas arbusculares.

\section{LITERATURE CITED}

Akiyama, K., and H. Hayashi. 2002. Arbuscular mycorrhizal funguspromoted accumulation of two new triterpenoids in cucumber roots. Bioscience Biotechnology and Biochemistry 66:762-769.

Ban, D., S. Goreta, and J. Borošić 2006. Plant spacing and cultivar affect melon growth and yield components. Scientia Horticulturae 109:238-243.

Ban, D., M. Oplanić, A.S. Ilak Peršurić, M. Radulović, B. Novak, I. Žutić, and S. Goreta. 2007. Effects of plug size, mycorrhizae inoculant and growth period on the development of watermelon transplants. Acta Horticulturae 731:137-142.

Ban, D., K. Žanić, G. Dumičić, T. Gotlin Čuljak, and S. Goreta Ban. 2009. The type of polyethylene mulch impacts vegetative growth, yield, and aphid populations in watermelon production. Journal of Food Agriculture and Environment 7:543-550.

Brinen, G.H., S.J. Locascio, and G.W. Elmstrom. 1979. Plant and row spacing, mulch, and fertilizer rate effects on watermelon production. Journal of the American Society for Horticultural Science 104:724-726

Chandanie, W.A., M. Kubota, and M. Hyakumachi. 2006. Interactions between plant growth promoting fungi and arbuscular mycorrhizal fungus Glomus mosseae and induction of systemic resistance to anthracnose disease in cucumber. Plant and Soil 286:209-217.

Duthie, J.A., B.W. Roberts, J.V. Edelson, and J.W. Shrefler. 1999. Plant density-dependent variation in marketable yield, fruit biomass, and marketable fraction in watermelon. Crop Science 39:412-417.

Edelstein, M., and H. Nerson. 2002. Genotype and plant density affect watermelon grown for seed consumption. HortScience 37:981-983.

FAOSTAT. 2010. FAO statistical databases. Agriculture. Available at http://faostat.fao.org/site/567/DesktopDefault. aspx?PageID=567\#ancor (accessed 17 March 2010).

Goreta, S., S. Perica, G. Dumičić, L. Bućan, and K. Žanić. 2005. Growth and yield of watermelon on polyethylene mulch with different spacings and nitrogen rates. HortScience 40:366-369.

Huitron-Ramirez, M.V., M. Ricardez-Salinas, and F. CamachoFerre. 2009. Influence of grafted watermelon plant density on yield and quality in soil infested with melon necrotic spot virus. HortScience 44:1838-1841.

Kaya, C., D. Higgs, H. Kirnak, and I. Tas. 2003. Mycorrhizal colonisation improves fruit yield and water use efficiency in watermelon (Citrullus lanatus Thunb.) grown under well-watered and water-stressed conditions. Plant and Soil 253:287-292.

Knavel, D.E. 1988. Growth, development, and yield potential of short-internode muskmelon. Journal of the American Society for Horticultural Science 113:595-599.

Maynard, E.T., and W.D. Scott. 1998. Plant spacing affects yield of 'Superstar' muskmelon. HortScience 33:2-54.

Meding, S.M., and R.J. Zasoski. 2008. Hyphal-mediated transfer of nitrate, arsenic, cesium, rubidium, and strontium between arbuscular mycorrhizal forbs and grasses from a California oak woodland. Soil Biology and Biochemistry 40:126-134.

Motsenbocker, C.E., and R.A. Arancibia. 2002. In-row spacing influences triploid watermelon yield and crop value. HortTechnology 12:437-440.

NeSmith, D.S. 1993. Plant spacing influences watermelon yield and yield components. HortScience 28:885-887.

Robinson, R.W., and D.S. Decker-Walters. 1997. Cucurbits. CAB International, Wallingford, UK.

Sanders, D.C., J.D. Cure, and J.R. Schultheis. 1999. Yield response of watermelon to planting density, planting pattern, and polyethylene mulch. HortScience 34:1221-1223.

Sari, N., O. Ibrahim, and H. Yetisir. 2002. Effect of mycorrhiza inoculation on plant growth, yield, and phosphorous uptake in garlic under field conditions. Communications in Soil Sciences and Plant Analysis 33:2189-2201. 
SAS Institute. 1999. SAS/STAT User's guide. SAS Institute, Cary, North Carolina, USA.

Sensory, S., S. Demir, O. Turkmen, C. Erdinc, and O.B. Savur. 2007. Responses of some different pepper (Capsicum annum L.) genotypes to inoculation with two different arbuscular mycorrhizal fungi. Scientia Horticulturae 113:92-95.

Smith, S.E., and D. Read. 2008. Mycorrhizal symbiosis. $3^{\text {rd }}$ ed. Academic Press and Elsevier, London, UK.

Westphal, A., N.L. Snyder, L.J. Xing, and J.J. Camberato. 2008. Effects of inoculation with mycorrhizal fungi of soilless potting mixes during transplant production on watermelon growth and early fruit yield. HortScience 43:354-360.

Zhang, L., J. Zhang, P. Christie, and X. Li. 2008. Pre-inoculation with arbuscular mycorrhizal fungi suppresses root knot nematode (Meloidogyne incognita) on cucumber (Cucumis sativus). Biology and Fertility of Soils 45:205-211.

Žnidarčič, D., and J. Osvald. 1999. The influence of plant density and covering on yield of bell peppers (Capsicum annuum L.). Res. Rep. Biotechnical Faculty, University of Ljubljana 73:59-64. 